\title{
Immunological Relationships of NGF, BDNF, and NT-3: Recognition and Functional Inhibition by Antibodies to NGF
}

\author{
Richard A. Murphy, ${ }^{1}$ Ann Acheson, ${ }^{1,3, a}$ Robert Hodges, ${ }^{2}$ Julie Haskins, ${ }^{1}$ Cheryl Richards, ${ }^{1}$ Eileen Reklow, ${ }^{1}$ \\ Vera Chlumecky, ${ }^{1}$ Philip A. Barker, ${ }^{1,6}$ Ralph F. Alderson, ${ }^{3}$ and Ronald M. Lindsay ${ }^{3}$ \\ 'Department of Anatomy and Cell Biology and 'Department of Biochemistry, Faculty of Medicine, University of Alberta, \\ Edmonton, Alberta, Canada T6G 2H7 and ${ }^{3}$ Regeneron Pharmaceuticals, Tarrytown, New York 10591
}

\begin{abstract}
Polyclonal antibodies raised against mouse 2.5S NGF (mNGF) and against synthetic peptides made from hydrophilic portions of mNGF have been used to compare the immunological properties of mNGF, human recombinant brain-derived neurotrophic factor (hrBDNF), and human recombinant neurotrophin-3 (hrNT-3). Affinity-isolated antibodies raised against intact $\mathrm{mNGF}$ reacted with all three neurotrophins when tested by ELISA and totally or partially blocked the bioactivities of the proteins in survival assays of embryonic chicken sensory and sympathetic neurons. On Western blots, mNGF antibodies reacted with all three neurotrophins but less well with hrBDNF and hrNT-3 than with mNGF. Antibodies to hydrophilic peptides within NGF (amino acids 23-35, $59-67,69-79$, and 91-100) showed partial reactivity with some but not all of the neurotrophins when tested by ELISA and on Western blots. The peptide antibodies were also selectively effective in reducing the survival-promoting activity of the neurotrophins on sensory neurons. Results show that mNGF, hrBDNF, and hrNT-3 are immunologically related proteins and that $\mathrm{mNGF}$ antibodies react also with other members of the neurotrophin family.
\end{abstract}

[Key words: NGF, brain-derived neurotrophic factor, neurotrophin-3, neuronal survival, sensory neurons, sympathetic neurons]

NGF is the prototype member of the neurotrophin family of proteins that promote the survival and growth of selected neurons in the CNS and PNS. In addition to NGF, four members of the family have been identified: brain-derived neurotrophic factor (BDNF) (Barde et al., 1982; Leibrock et al., 1989),

\footnotetext{
Received Nov. 20, 1991; revised Nov. 30, 1992; accepted Jan. 25, 1993.

We thank Dr. James Miller and Mr. Robert Rosenfeld at Amgen (Thousand Oaks, CA) for providing hrBDNF and hrN'-3 and also Greg Morrison and Jaclyn Peebles for help in preparing the figures. We also thank Dr. Robert Campenot for carrying out the neurite growth assays. This work was supported by a Program Project grant (PG 46) from the Medical Research Council of Canada and by funds provided by the NCE Network in Neural Regeneration and Functional Recovery (R.A.M., A.A.), by a grant from the Medical Research Council (R.H.), by the Henry Toupin Foundation (R.A.M.), and by Establishment Grants from the Alberta Heritage Foundation for Medical Research (AHFMR) to A.A. and R.A.M. A.A. is supported by an AHFMR scholarship and P.A.B. by an AHFMR studentship.

Correspondence should be addressed to Richard A. Murphy, Ph.D., Montreal Neurological Institute, McGill University, 3801 University Avenue, Montréal, Québec, Canada H3A 2B4.

apresent address: Regeneron Pharmaceuticals, Tarrytown, NY 10591.

bPresent address: Department of Neurobiology, Stanford University School of Medicine, Stanford, CA 94305.

Copyright (C) 1993 Society for Neuroscience $0270-6474 / 93 / 132853-10 \$ 05.00 / 0$
}

neurotrophin-3 (NT-3) (Ernfors et al., 1990; Hohn et al., 1990; Jones and Reichardt, 1990; Maisonpierre et al., 1990; Rosenthal et al., 1990), neurotrophin-4 (NT-4) (Hallböök et al., 1991; Ip et al., 1992), and neurotrophin-5 (Berkemeier et al., 1991). All family members share $50-60 \%$ amino acid identity and contain six conserved cysteine residues, which in NGF form three intrachain disulfide bonds necessary for biological activity (Bradshaw, 1978).

NGF and BDNF bind to high- and low-affinity receptors on responsive neurons (Sutter et al., 1979; Rodriguez-Tébar and Barde, 1990). The low-affinity NGF receptor (LNGFR, p75) has been identified and cloned (Chao et al., 1986; Radeke et al., 1987). Three other transmembrane proteins, p140 proto-trkA, $\mathrm{p} 145^{\text {proto-t } r k \mathrm{~B}}$, and $\mathrm{gp} 145^{\text {proto- } r \text { k } \mathrm{C}}$, which are closely related, bind NGF/NT-3, BDNF/NT-3, and NT-3, respectively (Kaplan et al., 1991; Klein et al., 1991; Lamballe et al., 1991; Soppet et al., 1991; Squinto et al., 1991). The role of the LNGFR in modulating neurotrophin binding to the trk proteins or in transducing the NGF signal is unclear (Hempstead et al., 1991; Meakin and Shooter, 1991; Weskamp and Reichardt, 1991; Ibáñez et al., 1992; reviewed by Barker and Murphy, 1992); however, NGF, BDNF, and NT-3 bind with similar affinities to the LNGFR (Rodriguez-Tébar et al., 1990; Squinto et al., 1991). The distinct, sometimes nonoverlapping biological activities of the proteins and their affinities for different $t r k$ receptors suggest that subtle differences in the structures of the proteins must be important.

Previous work has suggested that the neurotrophins are immunologically related (Acheson et al., 1991) in addition to being chemically similar. Polyclonal antibodies raised against $2.5 \mathrm{~S}$ mouse NGF (mNGF) were found to reduce the BDNF-like activity secreted into medium conditioned by fibroblasts and Schwann cells. Antibodies to $\mathrm{mNGF}$ also reduced the biological activity of human recombinant BDNF (hrBDNF) and recognized hrBDNF on Western blots.

In this study, we have examined further the immunological relationships of the neurotrophins. Antibodies were generated against intact $\mathrm{mNGF}$ and hydrophilic peptides of $\mathrm{mNGF}$ predicted to be exposed on the protein's surface. These predictions were confirmed by a study published while these experiments were being carried out. McDonald et al. (1991) solved the crystal structure of $\mathrm{mNGF}$, showing that $\mathrm{mNGF}$ consists of an hydrophobic core made up of three antiparallel pairs of $\beta$-strands and three $\beta$-hairpin loop regions along with a region containing three consecutive reverse turns. The core region contains residues highly conserved between the neurotrophins, and the loop and reverse turn regions contain variable residues that may account 
for the different receptor specificities and bioactivities of the neurotrophins (McDonald et al., 1991). The peptides against which we raised antibodies are located in three of the four $\beta$-hairpin turns; our fourth antibody recognizes highly conserved regions within the neurotrophins, flanking the reverse turn region of mNGF.

Results show that antibodies raised against intact mNGF inhibit the survival-promoting effects of hrBDNF and hrNT-3 in assays of cultured embryonic chicken sensory and sympathetic neurons. NGF antibodies also recognize hrBDNF and hrNT-3 in ELISAs and hrBDNF on Western blots; reduced and denatured NT-3 was only slightly reactive. Antibodies raised against mNGF peptides also selectively recognize reduced and denatured forms of the neurotrophins and some inhibit their survival-promoting activity. We conclude that mNGF, hrBDNF, and hrNT-3 are immunologically related molecules and that antibodies to $\mathrm{mNGF}$, which are widely used for identifying NGF in immunoassays, for immunocytochemistry, and for blocking the function of NGF in vitro and in vivo, can react also with other neurotrophins.

\section{Materials and Methods}

\section{Preparation of neurotrophins}

2.5S NGF was isolated from mouse salivary glands according to the procedures of Mobley et al. (1976) as modified previously (Watson et al., 1985). The protein was essentially pure as analyzed by SDS-PAGE and contained approximately $2 \% \mathrm{~N}$-linked glycosylated NGF (Murphy et al., 1989). CHO cell-derived hrBDNF and hrNT-3 were generously supplied by Amgen.

A composite surface profile program (SURFACEPLOT) was used to identify antigenic sites in mNGF as predicted from hydrophilicity, accessibility, and flexibility calculations (Parker et al., 1986). Four peptides predicted by this analysis to be exposed on the surface of mNGF (amino acids 23-35, peptide A; 59-67, peptide B; 69-79, peptide C; and 91100 , peptide D) were synthesized according to the general procedures of solid-phase synthesis (Frickson and Merrifield, 1976) as modified previously (Parker and Hodges, 1985). Nonconjugated peptides were acetylated at their $\alpha$-amino group and amidated at their $\alpha$-carboxyl group. The peptides were purified by preparative reverse-phase HPLC and were homogeneous as judged by analytical reverse-phase chromatography (Strynadka et al., 1988). Peptides used for conjugation were isolated from a rapid reverse-phase HPLC purification to a purity greater than $70 \%$ as judged by analytical reverse-phase HPLC, and coupled to keyhole limpet hemocyanin $(\mathrm{KLH})$ for immunization or to BSA for ELISAs and for coupling to aftinity columns for the isolation of IgG, as previously described (Parker et al., 1986). All peptides were characterized by amino acid analysis using a Beckman model 6300 amino acid analyzer (Beckman Instruments Inc., Fullerton, CA). The correct primary ion molecular weights were confirmed by plasma desorption flight time mass spectrometry on a B1010N-20 (Applied Biosystems Inc., Foster City, CA). The peptides used for conjugation contained an $\mathrm{N}$-terminal photolabile probe for coupling to the carrier followed by norleucine to detcrmine peptide:carrier conjugation ratios by amino acid analysis and were amidated at their $\mathrm{C}$-terminal. Conjugation ratios of KLH:peptide and BSA:peptide were both 4:1 for peptide A, 7:1 and 10: 1 , respectively, for peptide $B, 4: 1$ for peptide $C$, and $6: 1$ and $8: 1$, respectively, for peptide D (Strynadka et al., 1988).

\section{Preparation of antisera}

New Zealand White rabbits were injected intradermally in four to six sites on the back with Freund's complete adjuvant containing either 50 $\mu \mathrm{g}$ of $2.5 \mathrm{~S} \mathrm{NGF}$ or $500 \mu \mathrm{g}$ of each peptide conjugated to KLH. One month later, the animals were boosted with equivalent amounts of each antigen in incomplete adjuvant, and bled through the marginal vein of the ear 1 and 2 weeks later. Serum was prepared and antibody titers were determined using single-site ELISA. These assays, done in 96-well plates, were carried out by coating each well with $20 \mathrm{ng}$ of BSA-peptide or 2.5S NGF. Following blocking with fetal calf serum (FCS; $3 \%$ in PBS), antisera diluted $10^{-1}$ to $10^{-8}$ in antibody buffer (3\% FCS in PBS containing $0.05 \%$ Tween 20 ) were added to each well, and rabbit IgG was detected with a goat anti-rabbit IgG coupled to HRP. The signal was developed with 2,2'-azino-di-[3-ethyl-benz-thiazoline sulfonic acid (6)] diammonium salt (Calbiochem) and absorbance at $414 \mathrm{~nm}$ was read after $1 \mathrm{hr}$ on an ELISA plate reader. Antisera reacted strongly to the peptides against which they were raised; antisera to peptides $\mathrm{A}$ and $\mathrm{B}$ were strongly reactive at dilutions up to $10^{--7}$, as were antisera to peptide $\mathrm{C}\left(10^{-5}\right)$ and antisera to peptide $\mathrm{D}\left(10^{6}\right)$. Antisera to 2.5S NGF reacted strongly with mNGF at the highest dilution tested $\left(10^{8}\right)$.

In some experiments, we used $\operatorname{lgG}$ isolated from sheep injected with 2.5S NGF according to protocols identical to those used for rabbits except that $100 \mu \mathrm{g}$ of antigen was used for the initial injection and for the 1 month boost. The animal was bled by inserting a needle into the jugular vein. Sheep IgG gave results in bioassays essentially identical to those obtained using rabbit anti-NGF IgG.

\section{Affinity isolation of antibody}

Affinity-isolated IgG was prepared from antisera raised against $2.5 \mathrm{~S}$ NGF or mNGF peptides. 2.5S NGF or BSA-conjugated peptides were covalently coupled to Affi-Gel 10 agarose beads (Bio-Rad) and specific IgGs isolated according to the manufacturer's instructions.

\section{Immunoblot analyses}

Immunoblot replicas of SDS polyacrylamide gels (Towbin et al., 1979) were incubated in a 5\% solution of skim milk powder in $25 \mathrm{~mm}$ Tris$\mathrm{HCl}, \mathrm{pH} 7.2$, containing $\mathrm{NaCl}(0.15 \mathrm{~m})$ and Tween $20(0.3 \%)$ to saturate binding sites on the nitrocellulose after protein transfer as well as for application of the primary and secondary antibodies. The same solution without skim milk powder was used for all washes. Immunoblots were developed with alkaline phosphatase-conjugated goat anti-rabbit IgG (Jackson Immunoresearch) and developed with nitro-blue tetrazolium and 5-bromo-4-chloro-3-indoyl phosphate. All blots were developed for the same amount of time.

\section{Biological assays}

Survival assays. Dorsal root ganglia (DRG) and sympathetic ganglia from embryonic day 8-10 (E8-E 10) chicken embryos were dissociated and cultured according to the method of Barde et al. (1980) as modified previously (Acheson et al., 1991). Medium containing mNGF and either normal rabbit IgG or IgG raised against $\mathrm{mNGF}$ or mNGF pcptides was incubated overnight at $4^{\circ} \mathrm{C}$ prior to being applied to cultured cells. Control cultures received no added trophic factors. Cell survival was measured after $3 \mathrm{~d}$ by counting the number of phase-bright neurons with neurites at least 5 cell body diameters long. Percentage survival was calculated as (number of neurons at day 3 )/(total cell number at day 0$) \times 100 \%$ for each dish in the experiment. In a set of experiments in which we tested the ability of synthetic peptides of mNGF to compete for the survival-promoting effects of $\mathrm{mNGF}$, we added $20 \mathrm{~nm}$ acetylated peptide to dishes containing 20 pM mNGF (for sensory neurons) or 40 pM mNGF (for sympathetic neurons) immediately before plating. Cell survival was measured as above.

Neurite outgrowth assays. Dissociated sympathetic neurons from newborn rat superior cervical ganglia were plated into the center compartment of three-compartmented culture dishes (Campenot, 1982). mNGF ( $2 \mathrm{nM}$ ) was added to medium in the center and left compartments of each dish at the time of plating; the right compartment received NGFcontaining medium preincubated overnight with affinity-purified $\mathrm{IgG}$ $(20 \mathrm{~nm})$. The cultures were incubated at $37^{\circ} \mathrm{C}$ and $2.8-3 \mathrm{~d}$ later neurite extension in individual tracks in the left and right compartments was measured as described (Campenot and Draker, 1989).

\section{RNA isolations and Northern blots}

RNA was isolated from $\mathrm{PCl} 2$ cells grown to approximately $80 \%$ confluence in $100 \mathrm{~mm}$ culture plates in HEPES-buffered Dulbecco's modified Eagle's medium supplemented with $10 \%$ horse serum and $5 \%$ FCS. For the experiments testing the ability of antibodies to mNGF and to mNGF peptides to inhibit NGF-induced increases in c-fos, we washed cultures three times in medium without serum, and added fresh medium containing mNGF (400 pM) together with $20 \mathrm{~nm}$ of the appropriate affinity-isolated IgG. Medium was also changed in control cultures not receiving antibody. After $30 \mathrm{~min}$, mRNA was isolated using the guanidinium hydrochloride method and Northern blots were carried out according to previously published methods (Acheson et al., 1991). The 
blots were probed with random-primed cDNA fragments derived from the entire rat c-fos open reading frame (Curran et al., 1987).

\section{PC12 binding assavs}

Binding assays were carried out to test the ability of anti-peptide antibodies and of synthetic peptides to interfere with the binding of radiolabeled mNGF to PC1 2 cells. For antibody studies, $\mathrm{I}^{125}$-labeled mNGF (tested at $100 \mathrm{pM}$ or $1 \mathrm{nM}$ final concentration) was preincubated with $20 \mathrm{nM}$ affinity-isolated IgG $30 \mathrm{~min}$ at $37^{\circ} \mathrm{C}$. For peptide competition studies, radiolabeled mNGF (1 nM) was preincubated with synthetic peptides $(10 \mathrm{~nm}$ or $1 \mu \mathrm{M})$ for the same time period. The samples $(0.2$ $\mathrm{ml}$ ) were diluted with an equal volume of buffer containing $5 \times 10^{6}$ cells $/ \mathrm{ml}$ and incubated at $37^{\circ} \mathrm{C}$ for $30 \mathrm{~min}$ with shaking. Aliquots from each tube were layered onto a $300 \mu \mathrm{l}$ sucrose cushion in binding buffer, centrifuged, and quickly frozen on dry ice. Radioactivity in the cell pellets and supernatants was measured in triplicate samples. Nonspecific binding was measured in tubes containing $2.6 \mu \mathrm{M}$ unlabeled mNGF.

\section{Statistical analyses}

Data were analyzed using the unpaired Student's $t$ test, and significance was evaluated from two-tailed $p$ values.

\section{Results}

SURFACEPLOT analyses predict that $m N G F, h r B D N F$, and hrNT-3 have similar surface profiles

Figure 1 shows that the primary sequences of mNGF, hBDNF, and hNT-3 (Hallböök et al., 1991), when analyzed by the suRFACEPLOT program (Parker et al., 1986), show similar predicted surface profiles. We selected and synthesized four peptides from the mNGF sequence that were predicted to be exposed to an aqueous environment and that covered the molecule within a minimum number of surface regions (indicated on the surface profile projection of $\mathrm{mNGF}$ as peptides A-D, Fig. 1). Crystallography studies of MacDonald et al. (1991) published after these peptides were prepared indicate that peptides $A$ and D are located in two of the three $\beta$-hairpin turn regions of NGF; peptide $\mathrm{B}$ is in the reverse turn region and is contiguous with peptide C. Table 1 shows the similarities of the four $\mathrm{mNGF}$ peptides used in this study to analogous portions of hBDNF and hNT-3. Amino acid identity within these regions ranges from $82 \%$ between $\mathrm{mNGF}$ and $\mathrm{hNT}-3$ in peptide $\mathrm{C}$ to a low of $11 \%$ between $\mathrm{mNGF}$ and $\mathrm{hBDNF}$ in peptide $\mathrm{B}$.

\section{Analysis of the interaction of denatured and reduced $m N G F$, $h r B D N F$, and $h r N T-3$ with antibodies to $M N G F$ and to $m N G F$ peptides}

To determine whether antibodies to $\mathrm{mNGF}$ or to MNGF peptides react with hrBDNF and hrNT-3, we tested the antibodies against reduced and denatured forms of the neurotrophins on Western blots. Figure $2 A$ shows the relative mobilities of the neurotrophins on 13-22\% gradient SDS-PAGE stained with Coomassie blue. In this gel system (Murphy et al., 1989), mNGF migrates in two bands, an upper A chain that is the intact monomer, and the lower B chain that is the desoctapeptide form of the protein (Bradshaw, 1978). Small amounts of glycosylated NGF (Murphy et al., 1989) are sometimes evident as well on Coomassie-stained gels (although not at the low loading concentration used for the gel shown in Fig. $2 A$ ), but can generally be detected on Western blots running slightly above mNGF (see Fig. $2 C$, top two sections). The mNGF dimer migrates faster than hrBDNF and hrNT-3, which have essentially identical mobilities. hrNT-3 migrates as two closely spaced bands (Fig. $2 A$ ) due to $15 \%$ of the material being heterogeneously $\mathrm{N}$-terminal cleaved (data not shown). On Western blot replicas of the

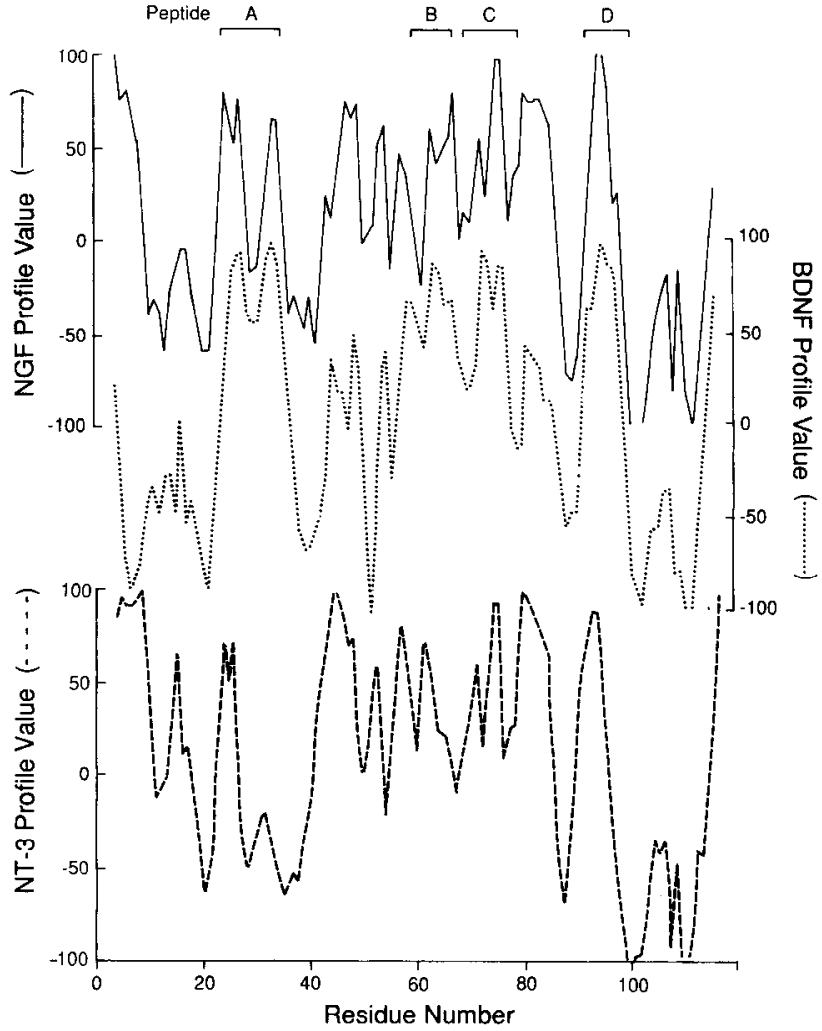

Figure 1. SURFACEPLOT analyses of mNGF, BDNF, and NT-3. The amino acid sequences of $\mathrm{mNGF}$ (top, solid line), hBDNF (middle, dotted line), and hNT-3 (bottom, dashed line) were analyzed and aligned using the SURFACEPLOT program (Parker et al., 1986) to identify portions of the molecules likely exposed to an aqueous environment. In each plot, peaks above the zero point on the ordinate denote regions of high surface potential (hydrophilic, flexible, and accessible) and the troughs denote regions of low surface potential. The suRFACEPLOT profiles of the three neurotrophins are highly similar. The bars at the top of the figure indicate peptides in the sequence of $\mathrm{mNGF}$ that were synthesized and against which rabbit antibodies were raised: peptide $A$, amino acids 23-35; peptide $B, 59-67$; peptide $C, 69-79$; and peptide $D, 91-100$.

gel (Fig. 2C), mNGF, and to lesser extents hrBDNF and hrNT3 , was detected by antibodies to intact mNGF. No signals were evident on blots treated with equivalent amounts of normal rabbit IgG. Antibodies to peptides A and B reacted strongly with $\mathrm{mNGF}$, less well with hrBDNF, and not at all with hrNT 3. Antibodies to peptides $\mathrm{C}$ and $\mathrm{D}$ reacted with $\mathrm{mNGF}$ and only slightly with hrBDNF and hrNT-3. Antibodies to mNGF and peptides $\mathrm{A}$ and $\mathrm{D}$ also reacted with glycosylated $\mathrm{mNGF}$, which migrates in samples of $\mathrm{mNGF}$ as a doublet in a position similar to hrNT-3 (Fig. $2 C$ ). The relative immunoreactivities of the neurotrophins on these blots cannot be accurately estimated, however, since mNGF appears to electroelute more effectively from the gels than either hrBDNF or hrNT-3 (Fig. 2B).

The neurotrophins react with $m N G F$ antibodies in neutral $p H$, nondenaturing buffers

Single-site ELISAs were carried out to test whether antibodies to $\mathrm{mNGF}$ and to $\mathrm{mNGF}$ peptides react with the neurotrophins in neutral $\mathrm{pH}$, nondissociating buffers. Figure $3 A$ shows that rabbit antibodies to $\mathrm{mNGF}$ (tested at eight concentrations ranging from 0.78 to $100 \mathrm{ng} /$ well) react with all three proteins. The strongest reaction was with $\mathrm{mNGF}$ (half-maximal reaction ob- 
Table 1. Comparison of the primary structures of peptides $A, B, C$, and $D$ in $m N G F$ to analogous segments of hBDNF and hNT-3

\begin{tabular}{|c|c|c|c|c|c|c|c|c|c|}
\hline mNGF & (amino acids 23-35) & G & $\begin{array}{ll}\mathrm{D} & \mathrm{K} \\
\end{array}$ & $\mathrm{T}$ & $\begin{array}{|ll|}\mathrm{T} & \mathrm{A} \\
\end{array}$ & $\mathrm{T}$ & $\mathrm{D}, \mathrm{I}$ & K & $\mathrm{G}$ \\
\hline hBDNF & (amino acids 23-35) & A & D K & $\mathrm{K}$ & $\begin{array}{ll}T & A\end{array}$ & $\mathrm{~V}$ & D $M$ & $\mathrm{~S}$ & $\mathrm{G}$ \\
\hline hNT-3 & (amino acids 22-34) & $\mathrm{T}$ & D $\mathrm{K}$ & $\mathrm{S}$ & $S A$ & I & $\mathrm{D} \mid \overline{\mathrm{I}}$ & $\mathbf{R}$ & $G$ \\
\hline
\end{tabular}

a.a. identity to $\mathrm{mNGF}$

hNT-3

\section{Peptide B}

$\begin{array}{ll}\text { mNGF } & \text { (amino acids 59-67) } \\ \text { hBDNF } & \text { (amino acids 59-67) } \\ \text { hNT-3 } & \text { (amino acids 58-66) }\end{array}$

$11 \%$

$33 \%$
$46 \%$

$46 \%$

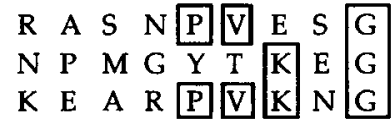

\section{Peptide C:}

mNGF

(amino acids 69-79)

hBDNF (amino acids 69-79)

hNT-3

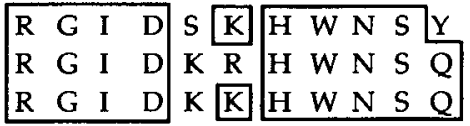

$73 \%$

$82 \%$

\section{Peptide D:}

\begin{tabular}{|c|c|c|c|c|c|c|c|c|}
\hline mNGF & (amino acids 91-100) & $\mathrm{T}$ & $\mathrm{T}$ & $\mathrm{E}$ & $\mathrm{K}$ & Q A A & W R & \\
\hline hBDNF & (amino acids 91-101) & $\mathrm{T}$ & $\mathrm{M} D$ & $\mathrm{~S} \quad \mathrm{~K}$ & $\mathrm{~K}$ & $R I G$ & W $\quad \mathrm{R}$ & $45 \%$ \\
\hline hNT-3 & (amino acids $90-100$ ) & $\mathrm{T}$ & $S E$ & $\mathrm{~N} \mathrm{~N}$ & $\mathrm{~K}$ & $\mathrm{~L} \quad \mathrm{~V} \mathrm{G}$ & W $\quad \mathrm{R}$ & $36 \%$ \\
\hline
\end{tabular}
of hBDNF and hNT-3 (from Hallböök et al., 1991). Amino acid identities compared to mNGF are listed on the right side of the table.

tained with $7 \mathrm{ng}$ of IgG per well). hrNT-3 was less reactive than mNGF (half-maximal reaction with $19 \mathrm{ng}$ of $\mathrm{IgG}$ ) but significantly more reactive than hrBDNF (optical density with $100 \mathrm{ng}$ of IgG approximately half that for NT-3). We obtained similar results with two additional antibodies to mNGF, one raised in rabbit and another in sheep (generously provided by Dr. Jack Diamond, McMaster University; data not shown).

The anti-peptide antibodies were less reactive in ELISAs with the neurotrophins than antibodies to intact mNGF (Fig. $3 B-$ $D$ ). Tested against mNGF (Fig. $3 B$ ), antibody to peptide A gave maximum absorbance of 1.89 with half-maximal absorbance occurring at $15 \mathrm{ng}$ of IgG, and antibody to peptide B gave maximal absorbance of 0.65 with half-maximal readings occurring with $50 \mathrm{ng}$ of IgG. Antibodies to peptides C and D reacted above control values only at IgG concentrations of 50 and $100 \mathrm{ng}$. Figure $3 C$ shows that antibodies to peptides A, B, and $C$ reacted with hrBDNF only slightly at IgG concentrations of 50 and $100 \mathrm{ng}$; antibody to peptide $D$ was unreactive against hrBDNF when tested in this assay. hrNT-3 was essentially unrecognized by the four peptide antibodies as well, although detectable signals just above those of the controls treated with normal rabbit IgG were measured at IgG concentrations of 50 and $100 \mathrm{ng}$ (Fig. 3D).

\section{Antibodies to $m N G F$ peptides selectively alter the activity of $m N G F$ in standard biological assays}

We questioned whether antibodies to mNGF peptides inhibit the biological activity of $\mathrm{mNGF}$ in standard biological assays. Under conditions where antibodies to intact NGF were fully inhibitory, antibodies to mNGF peptides were ineffective in blocking mNGF-induced increases in c-fos $\mathrm{mRNA}$ in $\mathrm{PC} 12$ cells (Greenberg et al., 1985), in reducing the binding of radiolabeled mNGF to PC1 2 cells, or in inhibiting mNGF-induced neurite outgrowth from rat sympathetic neurons grown in a compartmented tissue culture chamber (Campenot, 1982). In addition, none of the peptides competed with radiolabeled $\mathrm{mNGF}$ for receptors on PC12 cells. Since all of these data are negative, none are shown.

In survival assays for chick neurons, however, several of the anti-peptide antibodies partially reduced mNGF's effects. Inhibition was observed only when the survival assays were run under conditions that favored the ability of low-affinity antibodies to affect the actions of mNGF. These culture conditions included (1) using $\mathrm{mNGF}$ concentrations that gave half-maximal neuronal survival $(0.5 \mathrm{ng} / \mathrm{ml}$ for sensory neurons and $1 \mathrm{ng} /$ $\mathrm{ml}$ for sympathetic neurons, (2) taking care to minimize the number of non-neuronal cells present in the culture, and (3) culturing neurons at low density $\left(200-300\right.$ cells $/ \mathrm{cm}^{2}$ for sensory neurons and $500-700 \mathrm{cells} / \mathrm{cm}^{2}$ for sympathetic neurons).

Antibodies to intact mNGF blocked the effects of mNGF in promoting the survival of chicken sensory neurons, reducing survival from $27.8 \%$ to $4.4 \%$, a value similar to that obtained in control cultures grown in medium not containing NGF (Fig. $4 A$ ). Antibodies to peptides $A$ and $C$ had no effect on survival, but antibodies to peptides B and D inhibited survival by $85 \%$ and $53 \%$, respectively $(p<0.001)$. Similarly, antibody to intact mNGF reduced sympathetic neuronal survival by $98 \%$ and antibodies to peptide B reduced survival by $40 \%(p<0.01)$ (Fig. $4 B$ ). Antibody to peptide $D$ was also effective, although when compared to cultures treated with NGF alone, the differences 
$(p<0.135)$ were not significant at the $95 \%$ confidence level. Antibodies to peptides $\mathrm{A}$ and $\mathrm{C}$ were ineffective in blocking NGF-induced survival of sympathetic neurons.

We also tested whether acetylated peptides interfere with mNGF-induced neuronal survival. Peptides B and D, when tested at a 1000-fold molar excess, reduce the survival-promoting effects of mNGF on sensory neurons by $54 \%$ and $29 \%$, respectively ( $p<0.001$; Fig. $4 C$ ), while peptides $\mathrm{A}$ and $\mathrm{C}$ were ineffective. When tested against sympathetic neurons, peptide $\mathrm{B}$ reduced $\mathrm{mNGF}$-induced survival $(p<0.002)$ and peptides $\mathrm{C}(p<0.095)$ and $\mathrm{D}(p<0.077)$ were marginally effective. In control experiments, none of the peptides tested at the same concentration reduced the survival-promoting activity of ciliary neurotrophic factor on sympathetic neurons, indicating that inhibition did not arise nonspecifically from material in the antibody-containing solutions (data not shown). The antibody studies as well as the peptide competition assays suggest that peptides B and D may play important roles in the survivalpromoting activity of $\mathrm{mNGF}$.

\section{Antibodies to $M N G F$ and to $M N G F$ peptides inhibit the survival-promoting effects of $h r B D N F$ and $h r N T-3$}

Antibodies to intact $\mathrm{mNGF}$ reduced the survival-promoting effects of hrNT-3 on chicken sensory neurons, as did antibody to peptide $\mathrm{D}$, reducing survival by $62 \%$ ( $p<0.0001$; Fig. $5 A$ ). Antibodies to peptides $\mathrm{A}, \mathrm{B}$, and $\mathrm{C}$ were ineffective in this assay. Figure $5 B$ shows that antibodies to intact $\mathrm{mNGF}$ blocked hrBDNF-induced sensory neuron survival by $57 \%(p<0.001)$, in good agreement with previous studies (Acheson et al., 1991). All anti-peptide antibodies were partially effective against hrBDNF as well, reducing survival from a maximum of $64 \%$ (anti-peptide $\mathrm{C} ; p<0.004$ ) to a minimum of $25 \%$ (anti-peptide $\mathrm{D} ; p<0.04)$.

Antibodies to intact mNGF that inhibited the survival-promoting effects of $\mathrm{mNGF}$ on sympathetic neurons also reduced the survival-promoting effects of NT-3 (Fig. 6). hrBDNF, which does not promote neurite outgrowth in organotypic cultures of chick sympathetic ganglia (Maisonpierre et al., 1990), does support some neuronal survival (approximately 30\%) that also was inhibited by antibodies to mNGF.

\section{Discussion}

Several lines of evidence show that NGF, BDNF, and NT-3, in addition to being structurally similar proteins, are immunologically related. Antibodies raised against $\mathrm{mNGF}$ react with hrBDNF and hrNT-3 in ELISAs carried out in neutral pH, nondissociating buffers (Fig. $3 A$ ), with hrNT-3 only slightly less reactive than intact $\mathrm{mNGF}$ (see also Rosenthal et al., 1990). hrBDNF reacted far less strongly than the other two proteins. These results suggest that the three neurotrophins must have chemically similar groups exposed on their surfaces when in solution. However, structural differences must also be important since antibodies raised against peptides $\mathrm{A}$ and $\mathrm{B}$ recognize $\mathrm{mNGF}$ but not hrBDNF or hrNT-3 (Fig. 3). Results showing the crossreactivity of antibodies to peptides $\mathrm{A}$ and $\mathrm{B}$ with native $\mathrm{mNGF}$ in ELISAs are similar both qualitatively and quantitatively to those of Ebendal et al. (1989). They report that antibodies to mNGF recognize a sequence identical to peptide $\mathrm{A}$. We confirmed this result and determined as well that the same peptide was partially recognized by a function-blocking monoclonal antibody (mAb) to mNGF (mAb 27/21, Boehringer Mannheim) (data not shown). This highly conserved region of mNGF must

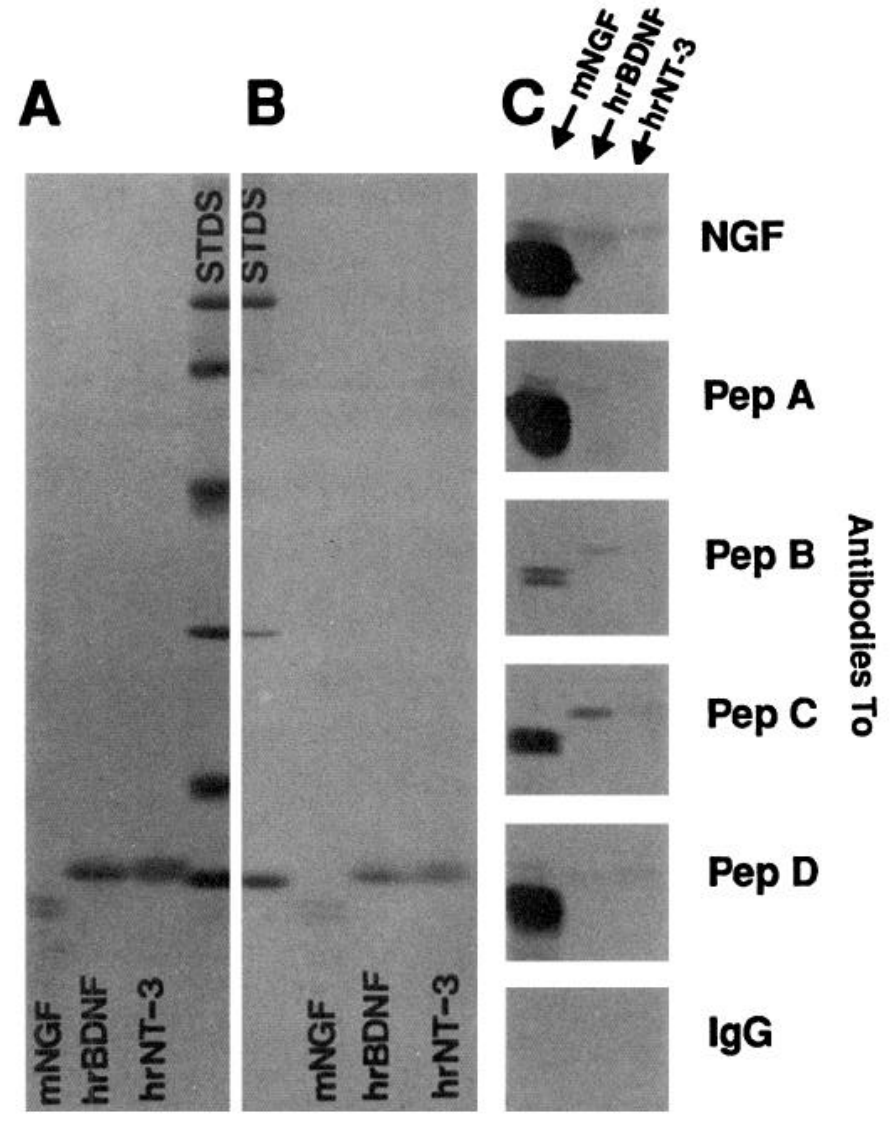

Figure 2. Western blot analyses of mNGF, hrBDNF, and hrNT-3. Samples of the neurotrophins $(500 \mathrm{ng} /$ well) were boiled $5 \mathrm{~min}$ in SDS sample buffer containing $5 \% \beta$-mercaptoethanol and electrophoresed on a 13-22\% gradient PAGE. The samples were transferred onto nitrocellulose for $3 \mathrm{hr}$ using the procedures of Towbin et al. (1979) and Western blots were developed with primary antibodies against mNGF and $\mathrm{mNGF}$ peptides $(1 \mu \mathrm{g} / \mathrm{ml})$ as described in Materials and Methods. $A$, Coomassie blue-stained polyacrylamide gel showing the relative migration positions of $\mathrm{mNGF}$, hrBDNF, and hrNT-3 along with molecular weight standards. $B$, Another segment of the same gel shown in $A$ following protein electroelution onto nitrocellulose for Western blotting. Under conditions where some high-molecular-weight protein standards are efficiently electroeluted, significant amounts of the low-molecularweight standard and of mNGF, hrBDNF, and hrNT-3 remain on the gel. $C$, Western blot replicas of mNGF, hrBDNF, and hrNT-3 treated with IgG against mNGF (top), peptides $A-D$, or normal rabbit IgG (lower panels) and developed with alkaline phosphatase-conjugated secondary antibody. Antibodies to $\mathrm{mNGF}$ and peptides $A-D$ react far more strongly with mNGF than with hrBDNF; hrNT-3 reacted only marginally with antibodies to mNGF and peptides $C$ and $D$ in this assay.

play an important role in the protein's antigenicity, as suggested previously (Ebdendahl et al., 1989).

Ibáñez et al. (1992) have shown by site-directed mutagenesis that the peptide A region of NGF is involved in regulating binding of the protein to the LNGFR but not to p140 proto-irkA, the receptor required for biological activity. In that regard, Longo et al. (1990) inhibited the survival-promoting activity of mNGF with synthetic peptides made from sequences within peptide A (residues 23-35), albeit at high concentrations; in our studies, peptide A did not interfere with the survival-promoting activity of $\mathrm{mNGF}$ and antibodies to peptide $\mathrm{A}$ were ineffective in blocking mNGF activity, results in agreement with those of Ebendal et al. (1989) and Ibáñez et al. (1990). 

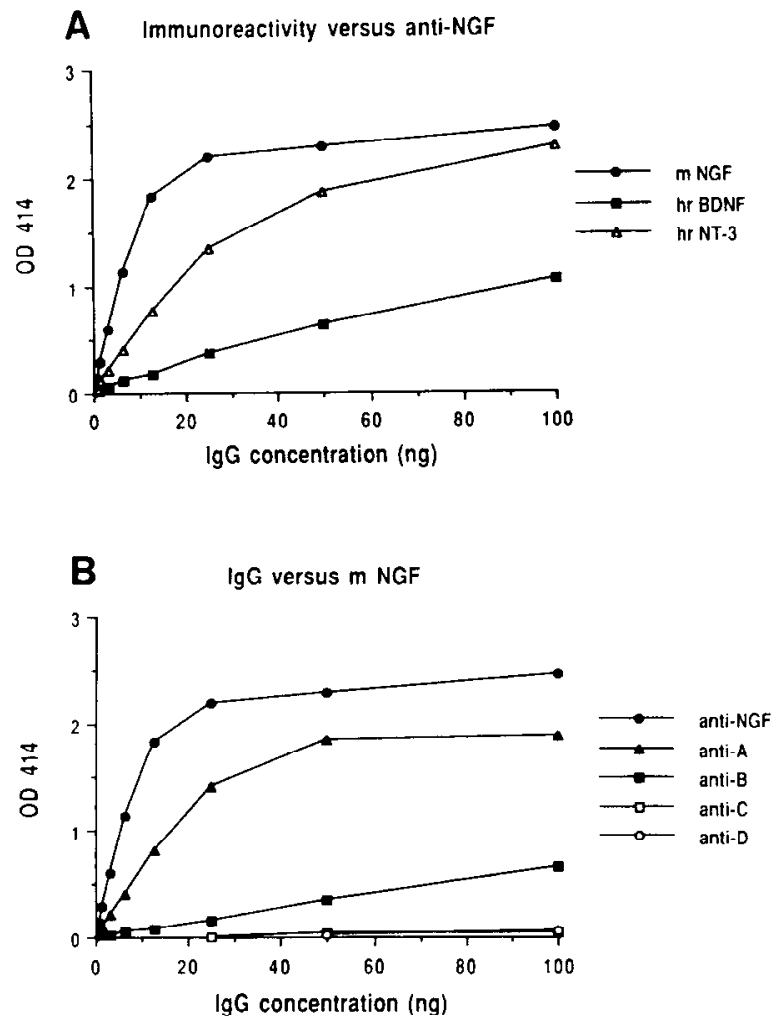
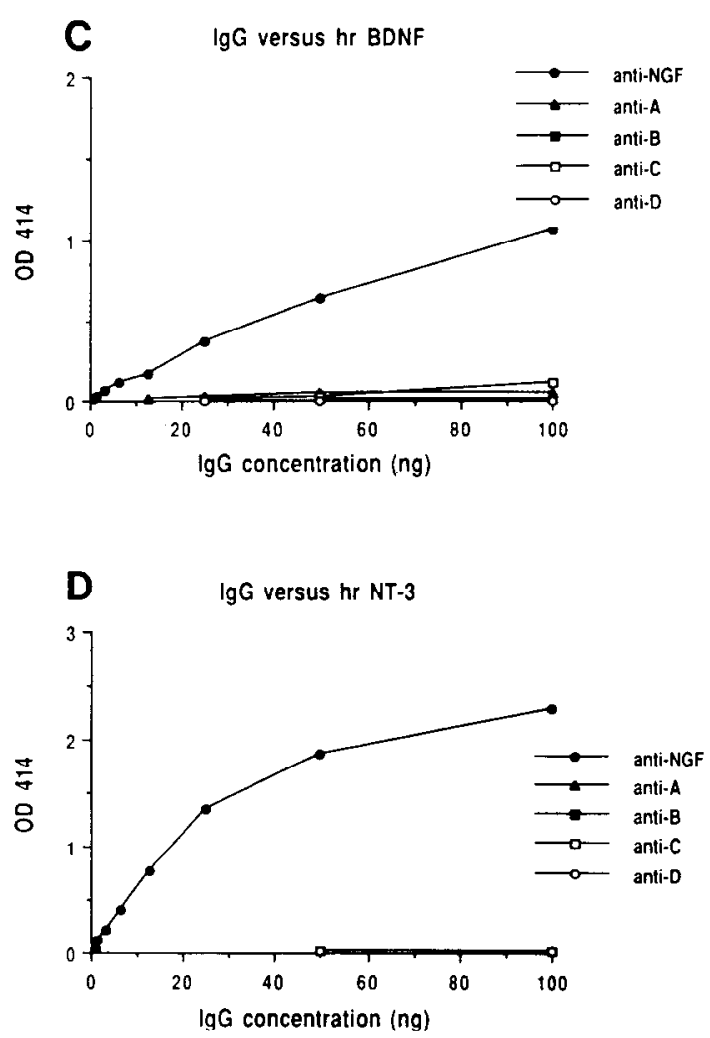

Figure 3. Single-site ELISAs testing the reactivity of the neurotrophins in nondenaturing buffer against antibodies to $\mathrm{mNGF}$ and $\mathrm{mNGF}$ peptides. Single-site ELISAs were carried out as described. $A$, Increasing concentrations of affinity-purified IgG raised against intact mNGF were used to detect $\mathrm{mNGF}$, hrNT-3, and hrBDNF (20 ng/well). The antibodies react with all three neurotrophins. $B-D$, Affinity-isolated IgG raised against mNGF and against $\mathrm{mNGF}$ peptides was used to detect $\mathrm{mNGF}(B), \operatorname{hrBDNF}(C)$, and $\mathrm{hrNT}-3(D)$. Antibodies to peptides $\mathrm{A}$ and $\mathrm{B}$ but not $\mathrm{C}$ and $\mathrm{D}$ reacted strongly with $\mathrm{mNGF}$, and none of the peptide antibodies reacted with hrBDNF or hrNT-3 except at the highest antibody concentrations tested (50 $\mathrm{ng}$ and $100 \mathrm{ng}$ ). Values are means of duplicate samples.

mNGF and to a much lesser extent hrBDNF were recognized following reduction and denaturation by antibodies to $\mathrm{mNGF}$ and to peptides A, B, C, and D on Western blots (Fig. 2). hrNT-3 was marginally recognized by antibodies to $\mathrm{mNGF}$ and to peptides C and D. Allendoerfer and Shatz (1991) have also reported that NT-3 and BDNF (see also Acheson et al., 1991) react with antibodies to NGF on Western blots.

The biological activities of mNGF, hrBDNF, and hrNT-3 are also either totally or partially inhibited by antibodies raised against mNGF. Antibodies to intact mNGF that blocked the ability of mNGF to induce c-fos production in PC12 cells, to stimulate neurite elongation from rat sympathetic neurons, to compete for $\mathrm{mNGF}$ for receptors on PC12 cells, and to promote the survival of embryonic chicken sensory and sympathetic neurons (Fig. 4) also reduced hrNT-3- and hrBDNF-induced survival of embryonic chicken sensory neurons (Fig. 5). The effectiveness of the antibodies roughly paralleled their ability to recognize hrNT-3 and hrBDNF in ELISAs (Fig. 3). Furthermore, $\mathrm{mNGF}$ antibodies blocked the survival-promoting activity of the neurotrophins on sympathetic neurons (Fig. 6). It has been reported that BDNF does not affect the survival of sympathetic neurons (Barde, 1989; Leibrock et al., 1989); in our experiments, hrBDNF had a marginal effect, promoting the survival of approximately $30 \%$ of E8 sympathetic neurons compared to survival rates of $75 \%$ and $60 \%$ induced by $\mathrm{mNGF}$ and hrNT-3, respectively (Fig. 6); $15 \%$ of the neurons at this developmental stage survived in the absence of added trophic factors. Perhaps a limited population of sympathetic neurons respond to hrBDNF or the protein acts at receptors for other neurotrophins to promote limited neuronal survival. Whatever the reason, the survival-promoting activity of hrBDNF on sympathetic neurons was also inhibited by antibodies to intact mNGF.

Antibodies to peptides of mNGF were partially effective in altering the biological activities of the neurotrophins but only in survival assays of embryonic chicken neurons (Figs. 4-6). Thesc antibodics werc incffective in blocking the effects of NGF to promote $\mathrm{c}$-fos induction in rat $\mathrm{PC} 12$ cells and neurite extension from rat sympathetic neurons. Also, in the studies of Ehendal et al. (1989) antibodies to similar peptides failed to block mNGF-promoted neurite growth from chicken sympathetic ganglia. Several factors may contribute to the lack of effectiveness of these antibodies in all bioassays tested. First, rat bioassays require relatively high levels of mNGF to obtain observable effects $(5-10 \mathrm{ng} / \mathrm{ml}$ for PC12 cells, and $50-200 \mathrm{ng} / \mathrm{ml}$ $\mathrm{mNGF}$ to induce neurite growth in sympathetic neurons in compartmented cultures) as do neurite growth assays of whole ganglia in chicken $(10-50 \mathrm{ng} / \mathrm{ml})$. These concentrations are 5100 -fold higher than we used for promoting survival of chicken embryonic neurons. Given the low affinity of the anti-peptide antibodies for $\mathrm{mNGF}$ (they failed to shift the elution position of small amounts of radiolabeled $\mathrm{mNGF}$ on a gel filtration column; data not shown), these antibodies probably cannot compete out high concentrations of the protein. In this regard, anti-peptide antibodies were most effective when used at a 1000 -fold molar excess of $\mathrm{mNGF}$ and when the number of neurons used in the 

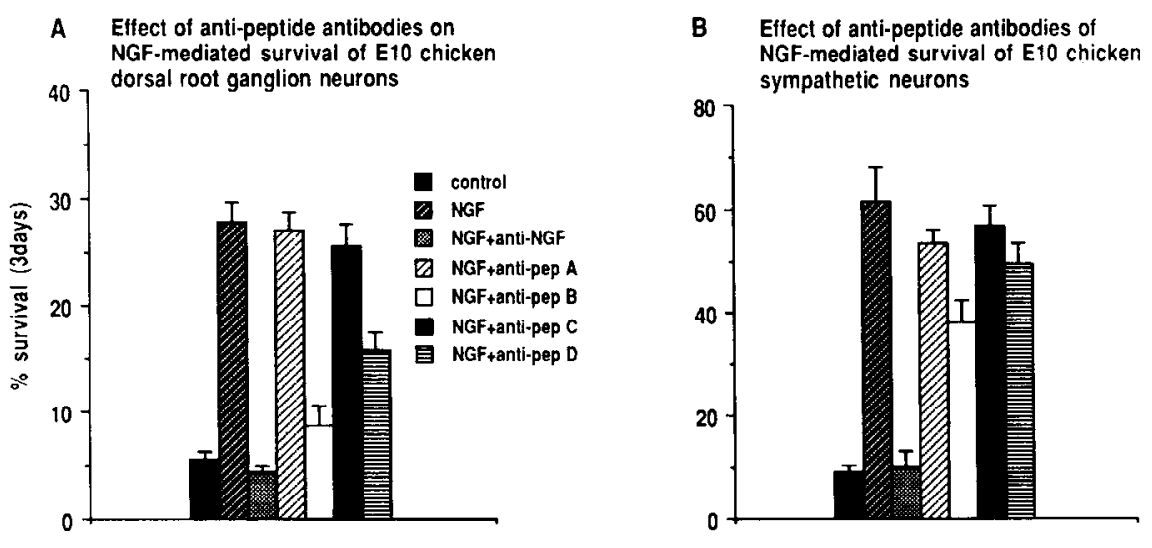

C Effect of mNGF peptides on NGF-mediated survival of sensory (DRG) and sympathetic (SG) E-10 chicken neurons
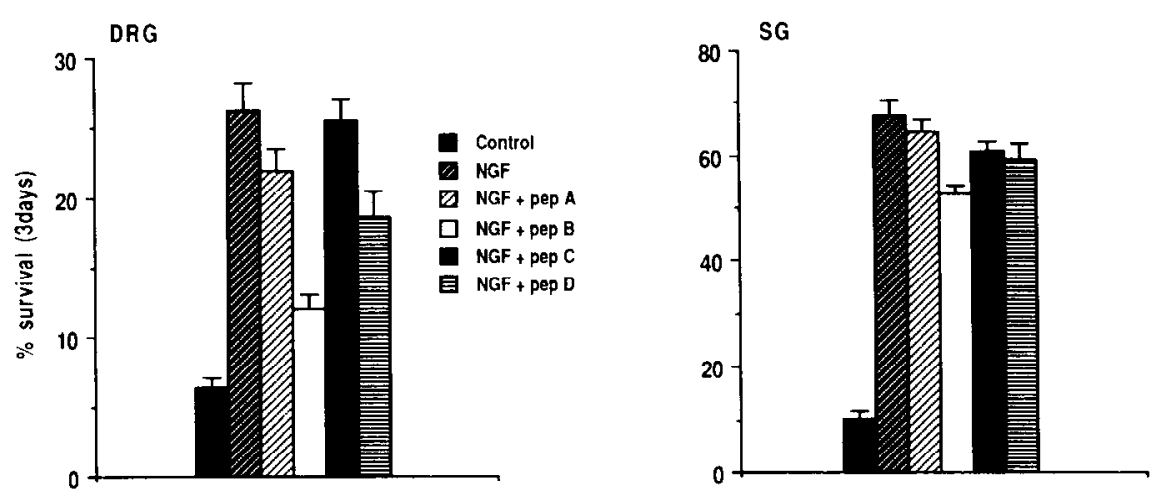

Figure 4. Survival assays of embryonic chicken DRG sensory and sympathetic neurons. $A$ and $B$, Survival assays for cultured sensory $(A)$ and sympathetic neurons $(B)$ were carried out as described in Materials and Methods using medium containing $0.5 \mathrm{ng} / \mathrm{ml} \mathrm{mNGF}$ for sensory neurons $(20 \mathrm{pm})$, and $1.0 \mathrm{ng} / \mathrm{ml}$ for sympathetic neurons $(40 \mathrm{pM})$, with or without $3.2 \mu \mathrm{g} / \mathrm{ml}(20 \mathrm{nM})$ affinity-isolated antibodies to mNGF or mNGF peptides. Control cultures received medium without $\mathrm{mNGF}$. Values represent the mean and SEM of five to eight experiments for sensory neurons (15-24 dishes per treatment) and seven experiments (21 dishes per treatment) for sympathetic neurons. Results indicate that antibodies to mNGF and to peptide B inhibited neuronal survival in both assays. Antibody to peptide $\mathrm{D}$ significantly inhibited the survival of sensory neurons $(p<0.0001)$ but reductions in the survival of sympathetic neurons were not significant $(p<0.135)$ at the $95 \%$ confidence level. Antibodies to peptides A and $C$ were not inhibitory in either assay. $C$, Survival assays testing the abilities of peptides A-D to compete out the survival-promoting effects of mNGF on embryonic sensory (left) and sympathetic (right) neurons. Sensory neurons were cultured in medium containing $20 \mathrm{~nm}$ acetylated peptides $(20 \mathrm{ng} / \mathrm{ml})$ and $0.5 \mathrm{ng} / \mathrm{ml} \mathrm{mNGF}(20 \mathrm{pM})$, and sympathetic neurons received medium containing $20 \mathrm{nM}$ acetylated peptide with $1 \mathrm{ng} / \mathrm{ml} \mathrm{mNGF}$ (40 pM). Control cultures received medium without mNGF. Values represent the mean and SEM of three independent experiments for sensory neurons (eight or nine cultures per treatment) and two experiments for sympathetic neurons (six cultures per treatment). Results show that peptides $\mathrm{B}$ and $\mathrm{D}$ significantly inhibited $\mathrm{mNGF}$-induced survival of sensory neurons $(p<0.0001)$. Peptide $\mathrm{B}$ was also inhibitory for mNGF-induced survival of sympathetic neurons, and peptides $\mathrm{C}(p<0.954)$ and $\mathrm{D}(p<0.0771)$ were marginally effective as well.

assays (and therefore the number of NGF receptors) was restricted to no more than was necessary for statistically valid measurements $\left(200-700\right.$ neurons $\left./ \mathrm{cm}^{2}\right)$. Second, the sequences of chicken and mouse NGF differ (amino acid identity in peptide $\mathrm{A}$ is $100 \%$; peptide $\mathrm{B}, 56 \%$; peptide $\mathrm{C}, 91 \%$; and peptide $\mathrm{D}$, $70 \%$; Meier et al., 1986) as do the sequences of the LNGFR in chicken and rat (Large et al., 1989). The mismatch between mouse and chicken NGF is greatest in peptides $B$ and $D$, which correlates well with the relative abilities of anti-peptides $B$ and $\mathrm{D}$ to block mNGF-mediated survival of chicken neurons. The mismatch in sequence together with the steric effects of antibody binding may be sufficient to inhibit NGF's effects on chicken neurons. Excess concentrations of peptides B and D partially reduce the survival-promoting activity of $\mathrm{mNGF}$ on chicken neurons as well (Fig. 4), data consistent with that explanation.

Antibodies to peptide B did reduce the survival-promoting activity of hrBDNF but not hrNT-3. The sequence represented by peptide $B$ is within a variable portion of NGF that is poorly conserved between species. Furthermore, only one amino acid in this region, a carboxy-terminal glycine, is identical between mNGF, hBDNF, and hrNT-3. For all of these reasons, it was surprising that antibodies to peptide $B$ were effective against mNGF and hrBDNF, but not hrNT-3.

Also effective in blocking the activities of all three neurotrophins in sensory neuron survival assays were antibodies to peptide D (residues 91-100; Figs. 4-6). This region shows a $45 \%$ amino acid identity between $\mathrm{hrBDNF}$ and $\mathrm{mNGF}$ and a $36 \%$ identity between hrNT-3 and mNGF, and has been implicated previously in the biological activity of chicken NGF. Ibáñez et al. (1990), using site-directed mutagenesis, found that replacing Arg 99 and Arg 102 with glycine impaired both the binding of mNGF to PC1 2 cells and the biological activity of chicken NGF in neurite outgrowth assays of chicken sympathetic ganglia. Both parameters were also affected by substituting trp-98, a residue conserved in BDNF and NT-3, with phenylalanine. More recently, Ibáñez et al. (1992) showed that substituting Lys 95 with 

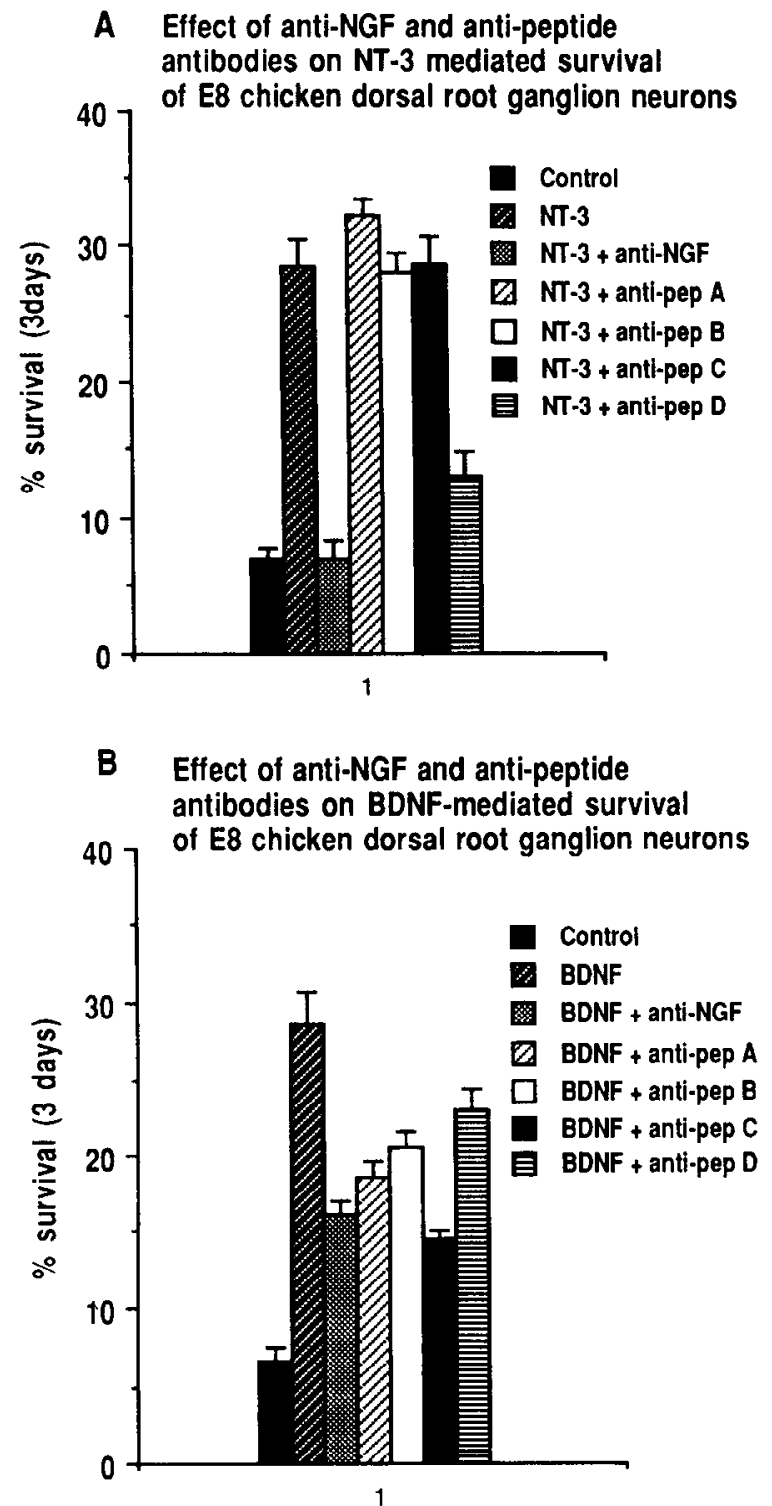

Figure 5. Survival assays for chicken DRG neurons cultured in medium containing hrNT-3 and hrBDNF and antibodies to mNGF and to $\mathrm{mNGF}$ peptides. Survival assays for sensory neurons were carried out as described in Materials and Methods using medium containing 5 $\mathrm{ng} / \mathrm{ml} \mathrm{hrNT}-3$ (200 pM) $(A)$ or $0.5 \mathrm{ng} / \mathrm{ml} \mathrm{hrBDNF}$ (20 pM) $(B)$ with 3.2 $\mu \mathrm{g} / \mathrm{ml}$ affinity-isolated $\mathrm{IgG}(20 \mathrm{~nm})$. In the studies with hrNT-3, values represent the mean and SEM of data collected from 9-24 dishes per treatment in six independent experiments. In studies using hrBDNF, data were collected in three independent experiments and values are from eight or nine dishes per treatment group. Results show that antibodies to intact mNGF significantly inhibited $(p<0.001)$ the survivalpromoting activity of hrNT-3 and hrBDNF. All of the anti-peptide antibodies inhibited the survival-promoting activity of hrBDNF (minimum $p$ value $<0.05$ ) but only antibody to peptide $D$ inhibited the survival-promoting activity of hrNT-3 $(p<0.0001)$.

Ala reduced $\mathrm{mNGF}$ binding to $\mathrm{PC} 12$ cells and enhanced the failure of forms of NGF mutated in the region of peptide $A$ to bind to LNGFR. Binding to p140 proto-rkA was only slightly diminished. In our studies, antibodies to peptide D reduced the survival-promoting activity on sensory neurons of mNGF by $33 \%$, hrBDNF by $25 \%$, and hrNT-3 by $71 \%$, effects that were significant statistically. Antibodies to peptide D were less effective in blocking the effects of mNGF on sympathetic neurons

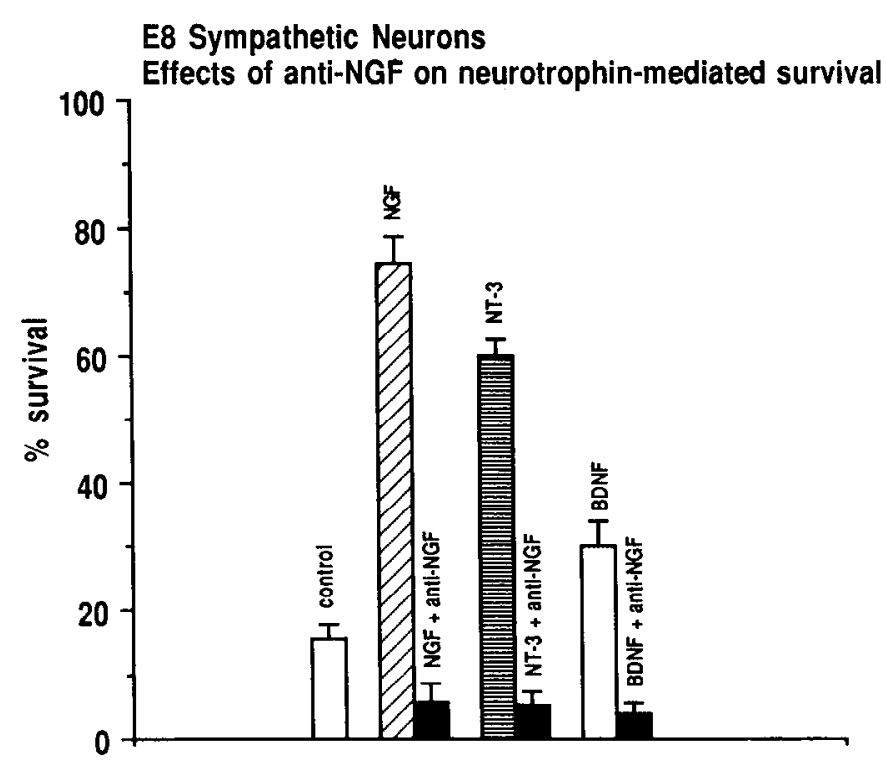

Figure 6. Survival assays of sympathetic neurons treated with neurotrophins and antibodies to mNGF. Survival assays were carried out using sympathetic neurons from E8 chicken embryos. Cultures received medium supplemented with either $1 \mathrm{ng} / \mathrm{ml} \mathrm{mNGF,} 5 \mathrm{ng} / \mathrm{ml} \mathrm{hrNT}-3$, or $0.5 \mathrm{ng}$ hrBDNF with $3.2 \mu \mathrm{g} / \mathrm{ml} \mathrm{IgG}(20 \mathrm{~nm}$ ) raised against intact $\mathrm{mNGF}$. Control cultures received medium without $\mathrm{mNGF}$. Values represent the mean and SEM of data collected in two independent experiments with five to seven cultures in each treatment group. Results show that antibodies to mNGF totally inhibited neurotrophin-stimulated neuronal survival.

(Fig. 6), reducing survival by $23 \%$, although this difference was not significant at the $95 \%$ confidence level. Our data taken together with those of Ibáñez et al. (1990) suggest that the region defined by peptide D (and perhaps its immediately surrounding amino acids) may play an important role in the biological activity of the neurotrophin family of proteins.

The reason that antibodies to peptides $B$ and $D$ reduced the survival-promoting effects of mNGF on embryonic chicken sympathetic neurons less well than on sensory neurons is difficult to explain. It is not due to the fact that higher levels of mNGF were needed to induce sympathetic neuronal survival since increasing concentrations of the antibodies did affect the results. Perhaps $\mathrm{mNGF}$ interacts differently with receptors on the two types of neurons. Indeed, this possibility seems likely given recent data showing that components of high-affinity NGF receptors in sensory and sympathetic neurons differ; embryonic mouse sensory neurons express $t r k \mathrm{~A}$, $t r k \mathrm{~B}$, and $t r k \mathrm{C}$ (Klein et al., 1990; Martin-Zanca ct al., 1990; N. Ip, unpublishcd obscrvation) whereas sympathetic neurons express predominantly trk A (Ip, unpublished observations).

Finally, antibodies to peptides $A$ and $C$ had no effect on the survival-promoting activity of $\mathrm{mNGF}$ on sensory or sympathetic neurons or on the effects of hrNT-3 on sensory neuronal survival. However, both antibodies partially reduced the survival-promoting activity of hrBDNF on sensory neurons that they recognize on Western blots, following reduction and denaturation. Therefore, despite clear immunological similarities between the neurotrophins, significant differences in primary structure must be important for their selective activities.

Since antibody specificities differ, we cannot from our studies assume that all polyclonal antibodies raised against mNGF react with all members of the neurotrophin family of proteins. Fur- 
thermore, we recognize that we have tested $\mathrm{mNGF}$ antibodies only against hrNT-3 and hrBDNF and that subtle species differences in the structures of neurotrophins from other sources may yield different immunological reactivities. However, the finding that some antibodies to mNGF react with other neurotrophins has significant implications. Antibodies to $\mathrm{mNGF}$ have been routinely used for immunocytochemistry to localize NGF in mouse and in other species and also as the basis for NGF radioimmunoassays and ELISAs. Furthermore, in numerous studies, polyclonal antibodies to mNGF injected into experimental animals have been used to identify sites of NGF action and also to uncover its role in neural growth and development. These results will need to be reevaluated since polyclonal antibodies against mNGF can clearly cross-react with both BDNF and NT-3. If immunological methods are to be used for measuring or localizing members of the neurotrophin family of proteins in vivo or for blocking their biological activities, antibodies specific for each protein must be used.

\section{References}

Acheson A, Barker PA, Alderson RF, Miller FD, Murphy RA (1991) Detection of brain-derived neurotrophic factor-like activity in fibroblasts and Schwann cells: inhibition by antibodies to NGF. Neuron 7:265-275.

Allendoerfer KL, Shatz CJ (1991) Neurotrophic factor family immunoreactivity is present in developing mammalian cortex. Soc Neurosci Abstr 17:221.

Barde Y-A (1989) Trophic factors and neuronal survival. Neuron 2:1525-1534.

Barde Y-A, Edgar D, Thoenen H (1980) Sensory neurons in culture: changing requirements for survival factors during development. Proc Natl Acad Sci USA 77:1199-1203.

Barde Y-A, Edgar D, Thoenen H (1982) Purification of a new neurotrophic factor from mammalian brain. EMBO J 1:549-553.

Barker P, Murphy RA (1992) The nerve growth factor receptor: a multicomponent system that mediates the actions of the neurotrophin family of proteins. Mol Cell Biochem 110:1-15.

Berkemeier LR, Winslow JW, Kaplan DR, Nikolics K, Goeddel DV, Rosenthal A (1991) Neurotrophin 5: a novel neurotrophic factor that activates trk and trkB. Neuron 7:857-866.

Bradshaw RA (1978) Nerve growth factor. Annu Rev Biochem 47: 191-216.

Campenot RB (1982) Development of sympathetic neurons in compartmented cultures. II. Local control of neurite survival by nerve growth factor. Dev Biol 93:1-12.

Campenot RB, Draker D (1989) Growth of sympathetic nerve fibers in culture does not require extracellular calcium. Neuron 3:733-743.

Chao MV, Bothwell MA, Ross AH, Koprowski H, Lanahan AA, Buck CR, Sehgal A (1986) Gene transfer and molecular cloning of the human NGF receptor. Science 232:518-521.

Curran T, Gordon MB, Rubino KL, Samubcetti LD (1987) Isolation and characterization of the $c$-fos (rat) cDNA and analysis of posttranslational modification in vitro. Oncogene 2:79-84.

Ebendal T, Persson H, Larhammar D, Lundstromer K, Otson L (1989) Characterization of antibodies to synthetic nerve growth factor (NGF) and proNGF peptides. J Neurosci Res 22:223-240.

Erickson BW, Merrifield RB (1976) Solid-phase peptide synthesis. In: The proteins, Vol II, 3d ed (Neurath H, Hill RL, eds), pp 257-527. New York: Academic.

Ernfors P, Ibáñez CF, Ebendal T, Olson L, Persson H (1990) Molecular cloning and neurotrophic activities of a protein with structural similarities to $\beta$-nerve growth factor: developmental and topographical expression in the brain. Proc Natl Acad Sci USA 87:5454-5458.

Greenberg ME, Greene LA, Ziff EB (1985) Nerve growth factor and epidermal growth factor induce rapid transient changes in proto-oncogene transcription in PC12 cells. J Biol Chem 260:14101-14110.

Hallböök F, Ibáñez CF, Persson H (1991) Evolutionary studies of the nerve growth factor family reveal a novel member abundantly expressed in Xenopus ovary. Neuron 6:845-858.

Hempstead BL, Martin-Zanca D, Kaplan DR, Parada LF, Chao MV
(1991) High affinity NGF-binding requires co-expression of the $t r k$ proto-oncogene product and the low affinity NGF receptor. Nature 350:678-683.

Hohn A, Leibrock J, Bailey K, Barde Y-A (1990) Identification and characterization of a novel member of the nerve growth factor/brainderived neurotrophic factor family. Nature 344:339-341.

Ibáñez CF, Hallböök F, Ebendal T, Persson H (1990) Structure function studies of nerve growth factor: functional importance of highly conserved amino acid residues. EMBO J 9:1477-1483.

Ibáñez CF, Ebendal T, Barbany G, Murray-Rust J, Blundel TL, Persson $\mathrm{H}$ (1992) Disruption of the low affinity receptor-binding site in NGF allows neuronal survival and differentiation by binding to the $t r k$ gene product. Cell 69:329-341.

Ip NY, Ibanez CF, Nye SH, McLain J, Jones PF, Gies DR, Belluscio L, LeBeau MM, Espinosa R, Squinto SP, Persason H, Yancopoulos $G$ (1992) Mammalian neurotrophin 4: structure, chromosomal location, tissue distribution, and receptor specificity. Proc Natl Acad Sci USA 89:3060-3064.

Jones KR, Reichardt LF (1990) Molccular cloning of a human gene that is a member of the nerve growth factor family. Proc Natl Acad Sci USA 87:8060-8064.

Kaplan DR, Hempstead BL, Martin-Zanca D, Chao MV, Parada LF (1991) The $t r k$ proto-oncogene product: a signal transducing receptor for nerve growth factor. Science 252:554-558.

Klein R, Martin-Zanca D, Barbacid M, Parada LF (1990) Expression of the tyrosine kinase receptor gene trk $\mathrm{B}$ is confined to the murine embryonic and adult nervous system. Development 109:845-850.

Klein R, Jing S, Nanduri V, O'Rourke E, Barbacid M (1991) The trk proto-oncogene encodes a receptor for nerve growth factor. Cell 65 : $189-197$.

Lamballe F, Klein R, Barbacid M (1991) trkC, a new member of the $t r k$ family of tyrosine kinases, is a receptor for neurotrophin-3. Cell 66:173-183.

Large TH, Weskamp G, Helder JC, Radeke MJ, Misko TP, Shooter EM, Reichardt LF (1986) Structure and developmental expression of the nerve growth factor receptor in the chicken central nervous system. Neuron 2:1123-1134.

Leibrock J, Lottspeich F, Hohn A, Hofer M, Hengerer B, Masiakowski $\mathrm{P}$, Thoenen H, Barde Y-A (1989) Molecular cloning and expression of brain-derived neurotrophic factor. Nature 341:149-152.

Longo FM, Vu TH, Mobley WC (1990) The in vitro biolngical effect of nerve growth factor is inhibited by synthetic peptides. Cell Regul $1: 189-195$.

Maisonpierre PC, Belluscio L, Squinto S, Ip NY, Furth ME, Lindsay RM, Yancopoulos GD (1990) Neurotrophin-3: a neurotrophic factor related to NGF and BDNF. Science 247:1446-1451.

Martin-Zanca D, Barbacid M, Parada LF (1990) Expression of the $t r k$ is restricted to the sensory cranial and spinal ganglia of neural crest origin in mouse development. Genes Dev 4:683-694.

McDonald NQ, Lapatto R, Murray-Kust J, Gunning J, Wlodawer A, Blundell TL (1991) New protein fold revealed by a 2.3-Å resolution crystal structure of nerve growth factor. Nature 354:411-414.

Meakin SO, Shooter EM (1991) Molecular investigations on the high affinity nerve growth factor receptor. Neuron 6:153-163.

Meier R, Becker-André M, Götr. R, Heumann R, Shaw A, Thoenen H (1986) Molecular cloning of bovine and chick nerve growth factor (NGF): delineation of conserved and unconserved domains and their relationship to the biological activity and antigenicity of NGF. EMBO J 5:1489-1493.

Mobley WC, Schenker A, Shooter EM (1976) Characterization and isolation of proteolytically modified nerve growth factor. Biochemistry 15:5543-5552.

Murphy RA, Chlumecky V, Smillie LB, Carpenter MA, Natriss M, Anderson JK, Rhodes JA, Barker PA, Siminoski K, Campenot RB, Haskins J (1989) Isolation and characterization of a glycosylated form of $\beta$ nerve growth factor in mouse submandibular glands. J Biol Chem 264:12502-12509.

Parker JMR, Hodges RS (1985) Photoaffinity probes provide a general method to prepare synthetic peptide conjugates. J Protein Chem 3:465478.

Parker JMR, Guo D, Hodges RS (1986) New hydrophilicity scale derived from high-performance liquid chromatography peptide retention data: correlation of predicted surface residues with antigenicity and $x$ ray-derived accessible sites. Biochemistry 25:5425-5432.

Radeke MJ, Misko TP, Hsu C, Herzenberg LA, Shooter EM (1987) 
Gene transfer and molecular cloning of the rat nerve growth factor receptor. Nature 325:593-597.

Rodriguez-Tébar A, Barde Y-A (1990) Binding of brain-derived neurotrophic factor to nerve growth factor receptor. Neuron 4:487-492.

Rosenthal A, Goeddel DV, Nguyen T, Lewis M, Shih A, Laramee GR, Nikolics K, Winslow JW (1990) Primary structure and biological activity of a novel human neurotrophic factor. Neuron 4:767-773.

Soppet D, Escandon E, Maragos J, Middlemas DS, Reid SW, Blair J, Burton LE, Stanton BR, Kaplan DR, Hunter T, Nikolics K, Parada LF (1991) The neurotrophic factors brain derived neurotrophic factor and neurotrophin-3 are ligands for the trk B tyrosine kinase receptor. Cell 65:895-903.

Squinto SP, Stitt TN, Aldrich TH, Davis S, Bianco SM, Radziejewski C, Glass DJ, Masiakowski P, Furth ME, Valenzuela DM, DiStefano PS, Yancopoulos GD (1991) trk B encodes a functional receptor for brain-derived neurotrophic factor and neurotrophin-3 but not nerve growth factor. Cell 65:885-893.
Strynadka NCJ, Redmond MJ, Parker JMR, Scraba DG, Hodges RS (1988) Use of synthetic peptides to map the antigenic determinants of glycoprotein D of herpes simplex virus. J Virol 62:3474-3483.

Sutter A, Riopelle RJ, Harris-Warrick RM, Shooter EM (1979) Nerve growth factor receptors. Characterization of two distinct classes of binding sites on chick embryo sensory ganglia cells. J Biol Chem 254: 5972-5982.

Towbin H, Staehlin T, Gordon J (1979) Electrophoretic transfer of proteins from polyacrylamide gels to nitrocellulose sheets: procedure and some applications. Proc Natl Acad Sci USA 76:4350-4354.

Watson AY, Anderson JK, Siminoski K, Mole JE, Murphy RA (1985) Cellular and subcellular co-localization of nerve growth factor and epidermal growth factor in mouse submandibular glands. Anat Rec 213:365-376.

Weskamp G, Reichardt LF (1991) Evidence that biological activity of NGF is mediated through a novel subclass of high affinity receptors. Neuron 6:649-663. 